\title{
EFEK MEDIASI AFFECTIVE COMMITMENT ANTARA PENGARUH JOB EMBEDDEDNESS TERHADAP TURNOVER INTENTION
}

\author{
Annisa Nana Nabella \\ Universitas Negeri Surabaya \\ Annisa.17080574136@mhs.unesa.ac.id
}

\begin{abstract}
The high turnover intention is a serious problem in various companies. It leads to an extraordinary misuse of assets and increases management costs. The turnover intention in employees could be explained from the micro (psychological) and macro (organizational and economic) sides. This research aimed to investigate and analyze job embeddedness and affective commitment on employees' turnover intention. This research uses a quantitative methodology to conduct a causality investigation. The survey of 85 employees was conducted in Mega Elektronik Nganjuk. The data were analyzed by PLS-SEM with SmartPLS (v.3.3.3). The study's findings put into words that job embeddedness has a negative and significant influence on turnover intention. Off the job embeddedness has no significant influence on turnover intention. On the job embeddedness has a positive and significant influence on affective commitment. Off the job embeddedness has a positive and significant influence on affective commitment. Affective commitment has a negative and significant influence on turnover intention. Affective commitment partially mediated the relationship between the job embeddedness and turnover intention. Affective commitment fully mediated the relationship between off the job embeddedness and turnover intention. The implication of this study is that the company should pay attention to employees who want to leave the company with good communication so the obstacles in work can be conveyed and get the best solution.
\end{abstract}

Keywords: affective commitment; off the job embeddedness; on the job embeddedness; turnover intention.

\section{PENDAHULUAN}

Kehadiran sumber daya manusia memiliki dampak pada kemajuan maupun kemunduran perusahaan. Jika sumber daya manusia di perusahaan berkembang dengan baik, maka perusahaan akan mendapatkan perkembangan yang baik, namun apabila sumber daya manusia dalam organisasi mengalami kemunduran, akan mengakibatkan turunnya kualitas perusahaan. Turnover pada karyawan merupakan pengunduran diri seorang karyawan baik secara disengaja maupun tidak disengaja (Suyono et al., 2020). Banyak perusahaan mengungkapkan turnover intention lebih berbahaya daripada turnover karena karyawan dengan turnover intention tidak memiliki semangat untuk bekerja sehingga berdampak pada produktivitas, menghambat kesuksesan, dan meningkatkan angka kecelakaan kerja (Takawira et al., 2014).

Merhar (2020) mengemukakan ketika seorang manajer menghasilkan $\$ 60.000$ dalam satu tahun, $\$ 30.000$ - \$45.000 merupakan biaya yang digunakan untuk perekrutan dan pelatihan. Untuk menjelaskan adanya fenomena turnover intention pada karyawan, ilmu sosial menawarkan penjelasan dari sisi mikro (psikologis) dan sisi makro (organisasi dan ekonomi) (Cho \& Son, 2012). Di sisi mikro, kepuasan kerja dan komitmen organisasi merupakan faktor yang dapat mengurangi turnover intention. Di sisi makro, penelitian ekonomi melihat kekuatan pasar serta tingkat pengangguran. Beberapa kasus turnover terjadi secara cepat misalnya karyawan yang berhenti karena adanya peristiwa atau kejadian di perusahaan, dan beberapa terjadi secara lambat misalnya ketidakpuasan dalam pekerjaan sehingga karyawan tetap bekerja dengan rasa tidak puas sembari mencari pekerjaan lainnya.

Fenomena turnover sering terjadi pada perusahaan di Indonesia. Perusahaan yang mengalami fenomena tersebut dan menjadi objek penelitian ini adalah Mega Elektronik Nganjuk, yang bergerak pada unit bisnis penjualan alat elektronik dan handphone. Berdasarkan wawancara pra-penelitian, terlihat bahwa banyak karyawan yang menginginkan untuk mengundurkan diri. Mengelola sumber daya yang baik berpengaruh untuk mengurangi tingkat perpindahan yang tinggi pada Mega Elektronik. Menurut wawancara dan data yang diperoleh, perusahaan yang akan diteliti mempunyai 
Annisa Nana Nabella. Efek Mediasi Affective Commitment antara Pengaruh Job Embeddedness terhadap Turnover Intention

tingkat turnover karyawan yang konstan dengan rata-rata 3\% per tahunnya. Terlihat bahwa adanya fenomena pada Mega Elektronik mengenai turnover intention juga didukung oleh pernyataan karyawan yang telah diwawancarai bahwa karyawan mengundurkan diri bukan karena meninggal, menikah, ataupun ikut dengan keluarga, melainkan karena adanya pabrik yang baru berdiri di Kabupaten Nganjuk.

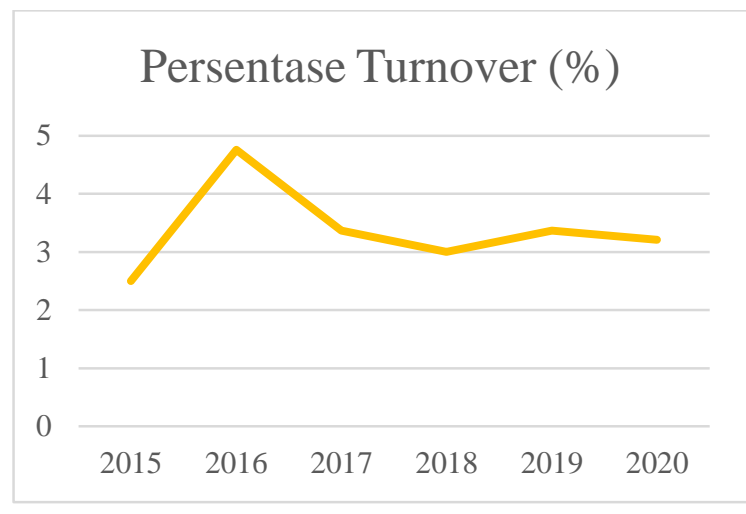

Sumber: Data diolah (2021)

\section{Gambar 1. TINGKAT TURNOVER MEGA ELEKTRONIK}

Meningkatkan komitmen karyawan mampu membuat karyawan bertahan pada perusahaan, sehingga turnover intention bisa berkurang (Hom et al., 2009). Menurut Zainuddin \& Noor (2019), sikap yang berhubungan dengan pekerjaan dan keterikatan emosional pada organisasi mampu membuat karyawan mempertahankan dirinya dalam organisasi. Organizational commitment memiliki tiga dimensi yaitu affective commitment (menunjukkan ketertarikan pada suatu pekerjaan dan keterikatan emosional pada organisasi), normative commitment (mengacu pada kewajiban atau bertahan pada posisi tertentu), dan continuance commitment (kesadaran akan biaya yang terkait apabila keluar dari organisasi) (Allen \& Meyer, 1990). Organizational commitment merupakan konstruksi multidimensi. Faloye (2014), Wasti (2003), dan Yang (2008) mengungkapkan affective commitment merupakan prediktor terkuat dalam memprediksi adanya turnover intention, sedangkan normative commitment merupakan prediktor paling lemah (Meyer et al., 1993). Namun, Uludag et al. (2011) mengungkapkan ketiga dimensi organizational commitment tidak berpengaruh signifikan terhadap turnover intention.

Variabel job embeddedness mampu menjelaskan mengapa karyawan bertahan di perusahaan (Mitchell et al., 2001). Ramesh \& Gelfand (2010) mengungkapkan bahwa sebagian besar karyawan meninggalkan perusahaan bukan karena perilaku buruk perusahaan, melainkan rasa puas terhadap pekerjaannya dan adanya kejadian yang tidak direncanakan. Job embeddedness menekankan bahwa tidak hanya faktor terkait pekerjaan (on the job) yang memengaruhi keputusan individu, melainkan komunitas (off the job) di dalamnya juga berperan (Lee et al., 2004). Konstruksi penting dari job embeddedness terdiri dari tiga elemen (fit, link, dan sacrifice) terhadap dua dimensi yaitu organisasi (on the job) dan komunitas (off the job). Tiga elemen tersebut adalah sejauh mana seseorang memiliki hubungan dengan orang atau aktivitas lain (links), sejauh mana pekerjaan dan komunitas seseorang sesuai dalam hidup mereka ( $f i t$ ), dan apa yang akan seseorang korbankan apabila pergi dari organisasi dan menyebabkan putusnya hubungan (sacrifice) (Mitchell et al., 2001). Meskipun Mitchell et al., (2001) membagi dimensi job embeddedness menjadi tiga (fit, link, sacrifice), namun studi sebelumnya membagi job embeddedness menjadi dua dimensi, yaitu on the job embeddedness dan off the job embeddedness (Felps et al., 2009; Lee et al., 2014; Ramesh \& Gelfand, 2010).

Menurut Crossley et al. (2007), seseorang yang terikat dengan organisasinya secara kuat, maka keinginan untuk keluar atau mencari organisasi lain semakin sedikit. Menurut Takawira et al. (2014), job embeddedness berpengaruh negatif lebih kuat terhadap turnover intention daripada work engagement. Menurut Thome \& Greenwald (2020), job embeddedness merupakan variabel terbaik untuk menjelaskan adanya turnover intention. Namun sebaliknya, Ampofo et al. (2017) 
mengungkapkan bahwa hanya on the job embeddedness berpengaruh signifikan dan negatif terhadap turnover intention, sedangkan off the job embeddedness tidak berpengaruh secara signifikan.

Job embeddedness memainkan peran penting dalam meningkatkan organizational commitment dan mengurangi turnover intention (Shehawy et al., 2018). Hyun \& Min (2010) menyatakan bahwa job embeddedness berpengaruh positif terhadap organizational commitment. Selain itu, Hom et al. (2009) menyatakan bahwa on the job embeddedness berpengaruh signifikan positif terhadap affective commitment. Pada beberapa studi yang sudah dilakukan, hanya terdapat beberapa yang melakukan uji pengaruh antara job embeddedness terhadap organizational commitment (Hom et al., 2009; Hyun \& Min, 2010; Kim \& Kang, 2015; Robinson et al., 2014; Shehawy et al., 2018). Sehingga melakukan penelitian pada kedua variabel tersebut dianggap penting. Pemahaman yang lebih baik tentang job embeddedness dan affective commitment akan memberikan implikasi yang baik tentang alasan mengapa karyawan memilih meninggalkan pekerjaan ketika karyawan tersebut nampak memiliki komitmen yang kuat. Apabila organisasi dan manajer tahu situasi ini lebih awal, mereka akan bersiap untuk menghadapi efek dari turnover. Karyawan yang terikat dengan pekerjaannya cenderung berkomitmen pada organisasinya, dan tidak berniat untuk pergi (Kim \& Kang, 2015). Penelitian ini memiliki tujuan untuk menguji dan menganalisis pengaruh job embeddedness terhadap turnover intention dengan efek mediasi affective commitment.

\section{KAJIAN PUSTAKA DAN PENGEMBANGAN HIPOTESIS}

\section{On the Job Embeddedness}

Job embeddedness merupakan gagasan yang dikembangkan oleh Mitchell et al. (2001) berfokus pada alasan mengapa seseorang bertahan dengan pekerjaannya daripada alasan mengapa seseorang meninggalkan perusahaan tersebut. Banyak penelitian job embeddedness memisahkan konstruksi keseluruhan menjadi dua dimensi yaitu on the job embeddedness dan off the job embeddedness (Coetzer et al., 2019; Lee et al., 2004; Robinson et al., 2014; Tian et al., 2016).

On the job embeddedness merupakan keterikatan dalam pekerjaan yang merupakan alasan mengapa seseorang bertahan dengan pekerjaannya (Clinton et al., 2012). On the job embeddedness yang tinggi mencerminkan banyaknya koneksi yang dimiliki, kesesuaian yang baik, dan hal penting yang akan dikorbankan seorang karyawan ketika berhenti dari pekerjaan (Lee et al., 2004). On the job embeddedness merupakan ikatan yang dimiliki dengan rekan kerja, kecocokan mutlak antara keterampilan dengan tuntutan pekerjaan dan layanan masyarakat terkait dengan organisasi (Faisal et al., 2020).

Indikator on the job embeddedness yang dikembangkan oleh Lee et al. (2004) yaitu: (1) link, sejauh mana seseorang memiliki hubungan dengan orang lain; (2) fit, sejauh mana seseorang dengan organisasinya memiliki kesesuaian dengan aspek dalam diri mereka; (3) sacrifice, kerugian yang ditimbulkan seseorang apabila meninggalkan sebuah pekerjaan.

\section{Off the Job Embeddedness}

Off the job embeddedness merupakan keterikatan di luar pekerjaan yang membuat karyawan tetap melekat pada pekerjaannya (Faisal et al., 2020). Apabila seorang karyawan menemukan dirinya cocok dengan komunitasnya, dalam dirinya akan timbul perasaan memiliki dan sikap positif ( $\mathrm{Yu}$ et al., 2020). Off the job embeddedness merupakan konstruksi yang memengaruhi pekerjaan dan kehidupan keluarga seorang pekerja yang membuat seseorang tetap berada di mana pun komunitas tersebut ada (Zainuddin \& Noor, 2019). Menurut Gonzalez et al. (2016), faktor yang memengaruhi off the job embeddedness yaitu transportasi, lingkungan yang berdekatan, demografis, dan dukungan sosial.

Off the job embeddedness mencerminkan sejauh mana karyawan memiliki keterikatan dengan komunitas tempat mereka tinggal (Singh et al., 2017). Karyawan dengan off the job embeddedness yang tinggi biasanya memiliki tingkat turnover dan ketidakhadiran yang lebih rendah dan performa kinerja yang lebih tinggi (Feldman et al., 2012; Jiang et al., 2012; Ng \& Feldman, 2014). Hal ini 
Annisa Nana Nabella. Efek Mediasi Affective Commitment antara Pengaruh Job Embeddedness terhadap Turnover Intention

berkaitan dengan sulitnya seseorang yang terikat untuk meninggalkan teman-temannya dan aktivitas yang terkait (Reitz \& Anderson, 2011). Jenis ketertarikan ini mencerminkan koneksi yang dimiliki seseorang dengan komunitas lokal dan jaringan sosial yang diperoleh (Treuren \& Fein, 2021).

Indikator off the job embeddedness yang dikembangkan oleh Lee et al. (2004) yaitu: (1) sejauh mana seseorang memiliki hubungan dengan orang lain di luar pekerjaan (link); (2) sejauh mana seseorang dengan komunitasnya memiliki kesesuaian dengan aspek dalam diri mereka (fit); (3) hubungan yang rusak jika meninggalkan komunitas (sacrifice).

\section{Affective Commitment}

Affective commitment merupakan salah satu dimensi dari organizational commitment. Affective commitment mengacu pada perasaan seseorang terhadap organisasinya (Meyer et al., 1993). Affective commitment merupakan hubungan emosional antara seseorang dengan organisasinya, keterlibatan anggota, dan identifikasi dengan organisasi (Hadi \& Nugraheni, 2018). Seseorang yang memiliki affective commitment yang tinggi akan bertahan dalam organisasinya karena adanya dorongan yang kuat untuk berada di organisasi (Wasti, 2003).

Karyawan mengenali kesamaan antara diri mereka dan organisasi, sehingga menunjukkan perhatian dan membentuk komitmen yang kuat (Firmanto \& Kistyanto, 2013). Affective commitment lebih memiliki pengaruh dibandingkan dengan normative commitment dan continuance commitment, karena dorongan internal dan motivasi individu lebih berpengaruh (Wasti \& Can, 2008). Usman et al. (2021) mengemukakan keyakinan yang kuat pada nilai dan tujuan organisasi, serta keinginan yang kuat untuk terlibat dalam perilaku kerja adalah salah satu manifestasi utama dari affective commitment.

Indikator affective commitment yang dikembangkan oleh Meyer et al. (1993) yaitu: (1) emotional attachment, terikat secara emosional dengan organisasi dan anggapan bahwa organisasinya adalah yang terbaik; (2) identification, perasaan bangga menjadi bagian dari organisasi; (3) involvement, ikut andil dalam pengembangan organisasi dan loyalitas.

\section{Turnover Intention}

Turnover adalah keinginan sukarela atau kejadian yang didefinisikan sebagai gerakan individu untuk melintasi batas keanggotaan organisasi (Price, 2000). Turnover intention adalah keinginan seseorang untuk mengubah pekerjaannya dalam jangka waktu tertentu (Sousa-Poza \& Henneberger, 2004). Karyawan yang meninggalkan perusahaan karena keinginan sendiri memiliki alasan yaitu ingin memperoleh gaji yang tinggi, mendapat penawaran yang baik, maupun fokus pada keinginan pribadi (Vandenberghe et al., 2011). Ketika seorang karyawan berniat untuk meninggalkan organisasi, karyawan tersebut melalui proses kognitif berpikir untuk berhenti, memiliki rencana untuk meninggalkan pekerjaan, dan keinginan meninggalkan pekerjaan (Peachey et al., 2014).

Menurut Lee et al. (2012), turnover intention mengacu pada tendensi karyawan untuk meninggalkan organisasi tempat mereka bekerja, dan pada akhirnya akan mengarah pada perilaku turnover. Turnover intention dapat berfungsi sebagai tanda perilaku turnover dan merupakan variabel yang paling sesuai untuk memprediksi perilaku turnover (Bambacas \& Kulik, 2013). Menurut Ridlo (2012), beberapa faktor yang memengaruhi turnover intention yaitu usia, masa kerja, tingkat pendidikan, keterikatan pada organisasi, kepuasan kerja, dan budaya perusahaan. Indikator turnover intention yang dikembangkan oleh Zhou et al. (2009) yaitu: (1) pemikiran untuk berhenti; (2) kemungkinan untuk mencari pekerjaan baru; dan (3) sedang mencari pekerjaan.

\section{Hubungan antar Variabel}

Banyak faktor yang memengaruhi turnover intention seperti job satisfaction, organizational commitment, dan job search (Hefny, 2020). Job embeddedness merupakan variabel unik yang digagas oleh Mitchell et al. (2001) yang mampu memprediksi adanya turnover melebihi faktor usia, kepuasan, komitmen, job search, dan perceived alternatives. Coetzer et al. (2019) mengemukakan on the job embeddedness berpengaruh secara negatif dan signifikan terhadap turnover intention pada UKM yang ada di Perth, Australia Barat. Selain itu, on the job embeddedness berpengaruh secara negatif dan 
signifikan terhadap turnover intention di industri laboratorium farmasi di Jabodetabek (Maska \& Riyanto, 2020). Berbeda dengan Lee et al. (2004), on the job embeddedness tidak memprediksi adanya turnover pada karyawan lembaga keuangan internasional.

H1: On the job embeddedness berpengaruh negatif dan signifikan terhadap turnover intention.

Off the job embeddedness mewakili salah satu gagasan dari job embeddedness yang memperhitungkan faktor non-kerja atau komunitas (Chan et al., 2019). Seorang karyawan dengan off the job embeddedness yang tinggi mampu mengatasi konflik pekerjaan dan kehidupan dan cenderung tidak ingin pergi ( $\mathrm{Ng} \&$ Feldman, 2014). Lee et al. (2004) mengungkapkan off the job embeddedness berpengaruh negatif dan signifikan terhadap turnover intention. Namun, berbeda dengan Allen (2006) dan Halbesleben \& Wheeler (2008) yang mengemukakan off the job embeddedness tidak berpengaruh secara signifikan terhadap turnover intention.

\section{H2: Off the job embeddedness berpengaruh negatif dan signifikan terhadap turnover intention.}

Hom et al. (2009) menjelaskan bahwa job embeddedness berpengaruh positif dan signifikan terhadap affective commitment pada manajer di China. Selain itu, job embeddedness berpengaruh positif dan signifikan terhadap organizational commitment pada karyawan hotel divisi food \& beverage di Korea (Hyun \& Min, 2010). Hal serupa juga dibuktikan oleh Kim \& Kang (2015) pada perawat di Korea, Robinson et al. (2014) pada karyawan hotel di Australia, dan Shehawy et al. (2018) pada karyawan industri penerbangan di Mesir yang menjelaskan job embeddedness berpengaruh positif dan signifikan terhadap organizational commitment. Menurut Treuren \& Fein (2021), semakin besar jumlah orang dalam jaringan, maka semakin besar akses seseorang tersebut ke dalam dukungan emosional dan informasi.

H3: On the job embeddedness berpengaruh positif dan signifikan terhadap affective commitment.

H4: Off the job embeddedness berpengaruh positif dan signifikan terhadap affective commitment.

Affective commitment merupakan prediktor terkuat dalam memprediksi adanya turnover intention. Hal ini dibuktikan oleh Wasti (2003) di Ankara, Turki dan Ahmad \& Shahid (2020) di Pakistan yang menunjukkan bahwa affective commitment berpengaruh signifikan negatif terhadap turnover intention lebih kuat dari kedua dimensi organizational commitment lainnya. Lew (2011) pada Curtin University Sarawak Malaysia, Joarder et al. (2011) di Dhaka, Bangladesh, dan Yang et al. (2019) di China mengungkapkan bahwa affective commitment berpengaruh signifikan negatif terhadap turnover intention. Berbeda dengan Harman et al. (2009) di Tirana, Albania yang mengungkapkan bahwa affective commitment tidak berpengaruh secara signifikan terhadap intention to leave.

H5: Affective commitment berpengaruh negatif dan signifikan terhadap turnover intention.

Job embeddedness membuka pandangan yang lebih luas tentang hubungan antara atasan \& bawahan maupun pekerja dengan pemilik usaha (Joarder et al., 2011). Affective commitment adalah dimensi yang paling langsung dan terkait dengan turnover intention (Ferreira \& Coetzee, 2013). Identifikasi psikologis \& emosional yang baik terhadap organisasi memainkan peran positif dalam mempromosikan minat mereka untuk mempertahankan pekerjaan (Zhou et al., 2009).

Ketika karyawan merasa terikat dengan organisasi dan komunitas yang ada, maka karyawan akan merasa senang bekerja dan melakukan tugas serta kewajibannya dengan baik, sehingga mampu mengurangi dampak terhadap turnover (Shafique et al., 2011). Karyawan yang terlibat dalam komunitas lokal maupun pekerjaannya cenderung memiliki tingkat integrasi sosial yang lebih tinggi dan mampu menciptakan potensi keterikatan secara emosional yang lebih besar (Mercurio, 2015). Karyawan dengan tingkat komitmen yang tinggi tidak hanya mencoba untuk terhubung dalam waktu yang lama dengan organisasi tetapi juga membuktikan sebagai aset bagi organisasi dengan efisiensi dan kekuatan yang ditingkatkan (Ali et al., 2011). 
Annisa Nana Nabella. Efek Mediasi Affective Commitment antara Pengaruh Job Embeddedness terhadap Turnover Intention

H6: Affective commitment memediasi pengaruh antara on the job embeddedness terhadap turnover intention.

H7: Affective commitment memediasi pengaruh antara off the job embeddedness terhadap turnover intention.

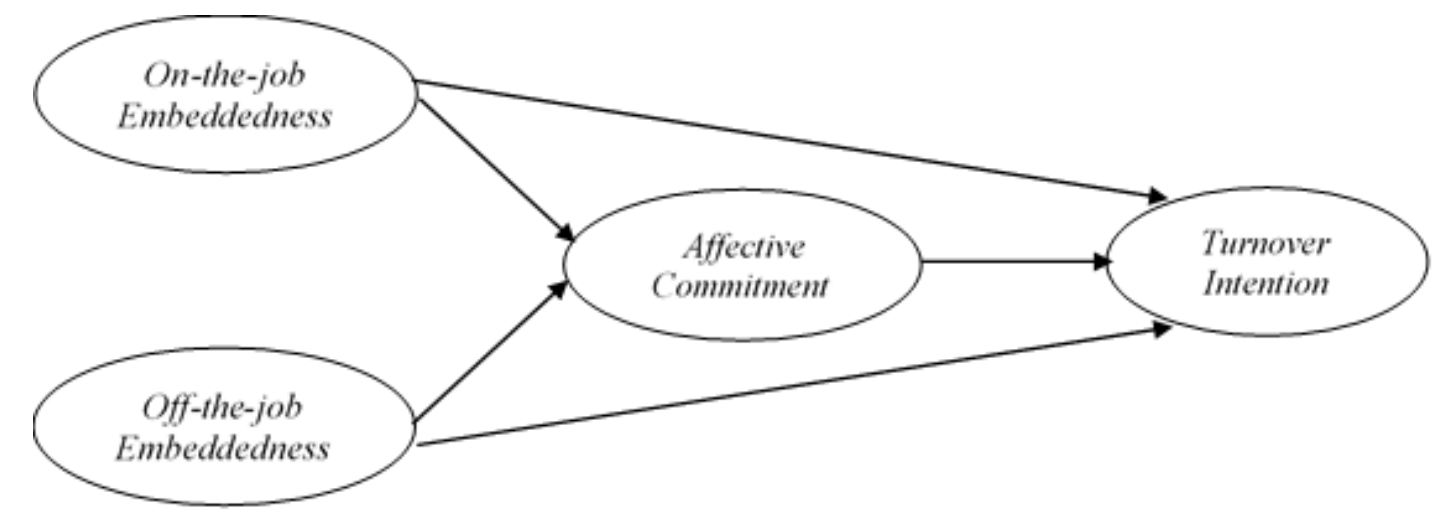

Sumber: Data diolah (2021)

Gambar 2. KERANGKA KONSEPTUAL

\section{METODE PENELITIAN}

Penelitian ini berjenis kausalitas yang menganalisis variabel job embeddedness dan affective commitment terhadap turnover intention dengan menggunakan metode kuantitatif. Sumber data penelitian ini adalah data primer dengan metode pengumpulan data meliputi penyebaran kuesioner secara luring, observasi, dan wawancara. Penelitian ini dilakukan pada Mega Elektronik Nganjuk, yang berlokasi di Jl. Ahmad Yani No. 62, Payaman, Kec. Nganjuk, Kabupaten Nganjuk, Jawa Timur. Penelitian ini menggunakan teknik probability sampling, dengan jenis simple random sampling. Populasi berjumlah 95 karyawan. Running data penelitian menggunakan SmartPLS (v.3.3.3) dengan pendekatan Structural Equation Modeling-Partial Least Square (SEM-PLS) dengan skala pengukuran likert 1-5.

\section{HASIL DAN PEMBAHASAN}

Data diambil menggunakan kuesioner/angket, dikarenakan penelitian ini menggunakan simple random sampling. Sampling penilaian melibatkan pilihan subjek yang paling menguntungkan untuk memberikan posisi terbaik, sebanyak 7 kuesioner tidak terisi dengan lengkap dan 8 kuesioner tidak kembali, sehingga data yang digunakan sejumlah 80 dari 95 jumlah populasi. Karakteristik responden diklasifikasikan berdasarkan karakteristik usia, status pernikahan, jenis kelamin, masa kerja, pendidikan, dan jabatan/departemen karyawan.

Karakteristik usia responden mencakup usia 20-25 tahun berjumlah 46 orang (57,5\%), 26-30 tahun berjumlah 27 orang $(33,8 \%)$, dan 31 tahun ke atas berjumlah 7 orang $(8,8 \%)$. Persentase jenis kelamin karyawan yaitu laki-laki berjumlah 62 orang $(77,5 \%)$ dan perempuan berjumlah 18 orang $(22,5 \%)$. Status karyawan dibagi menjadi dua, belum menikah sebanyak 32 orang (40\%) dan menikah sebanyak 48 orang $(60 \%)$. Karakteristik pendidikan responden yaitu SMA berjumlah 39 orang $(48,8 \%)$, SMK berjumlah 34 orang $(42,5 \%)$, MA berjumlah 4 orang $(5 \%)$, dan SMP berjumlah 3 orang $(3,8 \%)$. Masa kerja karyawan $\leq 1$ tahun sebanyak 23 orang $(28,8 \%), 2-5$ tahun berjumlah 50 orang $(62,5 \%)$, di atas 5 tahun berjumlah 7 orang $(8,8 \%)$. Jabatan koresponden meliputi frontliner sebanyak 32 orang (40\%), tim pemasaran sebanyak 20 orang (25\%), admin sebanyak 8 orang (10\%), tim warehouse sebanyak 10 orang (12,5), sopir berjumlah 3 orang $(3,8 \%)$, supervisor elektronik dan supervisor warehouse masing-masing berjumlah 2 orang (2,5\%), dan supervisor toko, supervisor handphone, serta asisten supervisor masing-masing sebanyak 1 orang $(1,3 \%)$. 
Analisis statistik deskriptif dilakukan dengan cara menghitung nilai rata-rata (mean) setiap pertanyaan dan keseluruhan jawaban. Karakteristik responden diklasifikasikan menggunakan interval kelas yang didapat dari rumus interval kelas yaitu 0,8 . Sehingga interval kategori responden yang didapat adalah (1) 4,20 < a $\leq 5,00$ (Sangat Tinggi). (2) 3,40 $<\mathrm{a} \leq 4,20$ (Tinggi). (3) 2,60 $<\mathrm{a} \leq 3,40$ (Sedang). (4) $1,80<\mathrm{a} \leq 2,60$ (Rendah). (5) 1,00< $\mathrm{a} \leq 1,80$ (Sangat Rendah). Adapun penjelasannya yaitu variabel on the job embeddedness dengan rata-rata variabel 4,17 (Tinggi), variabel off the job embeddedness dengan rata-rata variabel 4,06 (Tinggi), variabel affective commitment yaitu sebesar 3,86 (Tinggi), dan variabel turnover intention memiliki rata-rata indikator yaitu pada indikator pemikiran untuk keluar sebesar 2,24 (Rendah), indikator kemungkinan mencari pekerjaan baru sebesar 2,38 (Rendah), dan indikator sedang mencari pekerjaan sebesar 2,24 (Rendah).

\section{Convergent Validity}

Variabel yang memiliki nilai outer loading > 0,50 dinyatakan valid dan telah memenuhi syarat (Gozhali \& Latan, 2015). Namun perlu membuang beberapa outer loading (OnJE2, OnJE3, OnJE5, OnJE6, OnJE7, OnJE8, OnJE10,OnJE11, dan OnJE12) yang nilainya $<0,50$ untuk memenuhi ketentuan validitas.

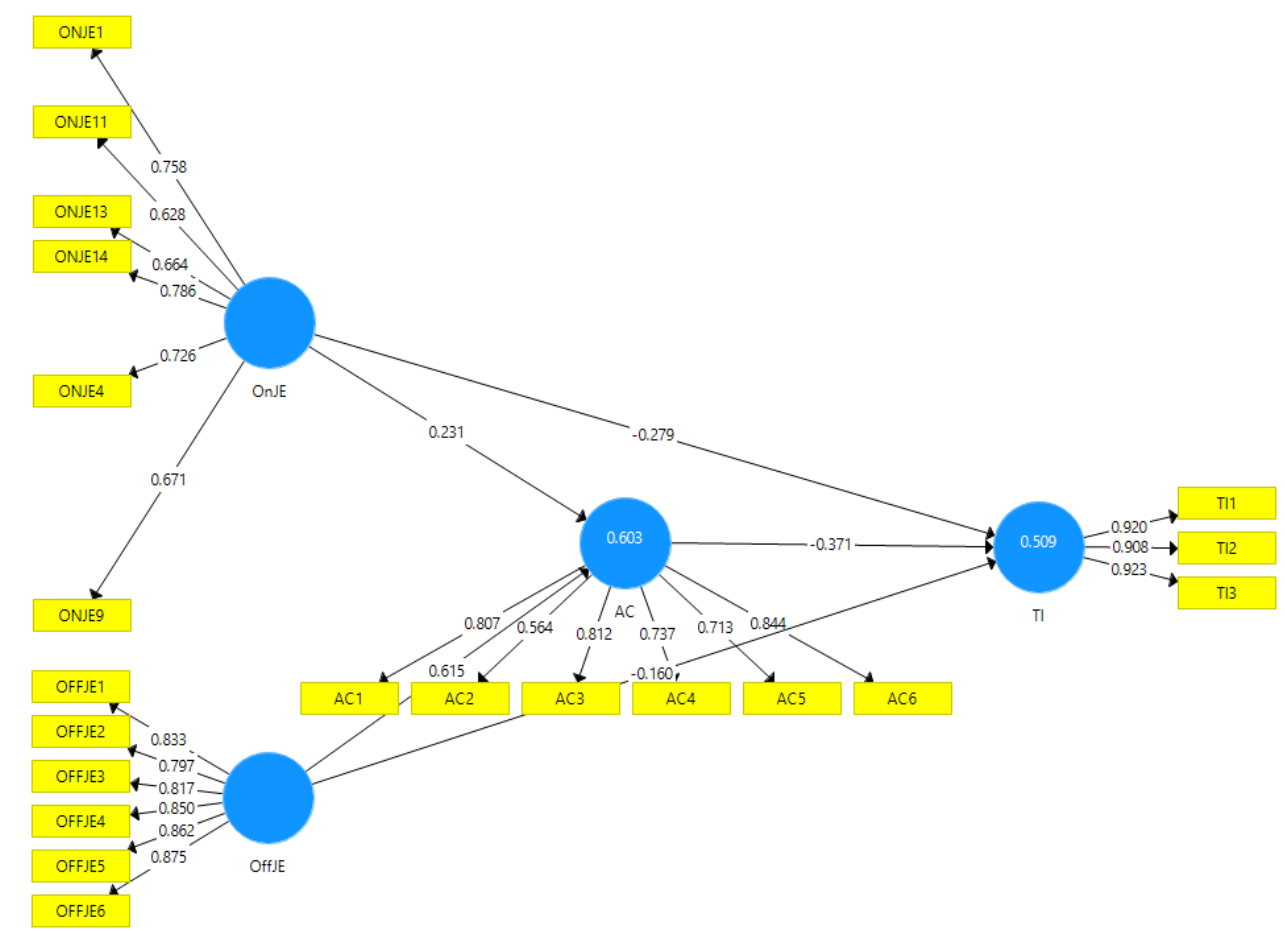

Sumber: Output SmartPLS (v.3.0) diolah

Gambar 3. MEASUREMENT MODEL

Composite Reliability \& Cronbach's Alpha

Tabel 1.

COMPOSITE RELIABILITY DAN CRONBACH'S ALPHA

\begin{tabular}{lcc}
\hline \multicolumn{1}{c}{ Variabel } & Composite Reliability & Cronbach's Alpha \\
\hline On the job embeddedness & 0,885 & 0,841 \\
Off the job embeddedness & 0,935 & 0,916 \\
Affective commitment & 0,857 & 0,800 \\
Turnover intention & 0,941 & 0,906 \\
\hline Sur
\end{tabular}

Sumber: Data diolah (2021)

Berdasarkan tabel 1 variabel on the job embeddedness memiliki nilai 0,885 >0,70, sehingga konstruk ini memiliki reliabilitas yang baik. Variabel off the job embeddedness memiliki nilai 0,935 tergolong 
Annisa Nana Nabella. Efek Mediasi Affective Commitment antara Pengaruh Job Embeddedness terhadap Turnover Intention

reliabilitas baik karena bernilai > 0,70. Variabel affective commitment memiliki nilai sebesar 0,857 tergolong memiliki reliabilitas baik karena $>0,70$. Variabel turnover intention memiliki nilai sebesar 0,941 tergolong memiliki reliabilitas baik karena $>0,70$.

\section{Analisis R-Square}

Berdasarkan tabel 2, R-Square job embeddedness terhadap affective commitment dapat diinterpretasikan bahwa variabel job embeddedness dapat menjelaskan affective commitment sebesar $60,3 \%$ sedangkan variabel lain yang tidak termasuk pada penelitian mampu menjelaskan sebesar $39,7 \%$. Variabel job embeddedness mampu menjelaskan turnover intention sebesar 50,9\% sedangkan variabel lain yang tidak termasuk pada penelitian mampu menjelaskan sebesar 49,1\%.

Tabel 2.

$R-S Q U A R E$

\begin{tabular}{lc}
\hline \multicolumn{1}{c}{ Variabel } & $\boldsymbol{R}$-Square \\
\hline Affective commitment & 0,603 \\
Turnover intention & 0,509 \\
\hline
\end{tabular}

Sumber: Data diolah (2021)

Tabel 3 menjelaskan penerimaan hipotesis $\mathrm{H} 1, \mathrm{H} 3, \mathrm{H} 4, \mathrm{H} 5, \mathrm{H} 6, \mathrm{H} 7$ dan penolakan pada hipotesis $\mathrm{H} 2$ dengan melihat dari coefficient estimateloriginal sample dan $t$-statistic.

Tabel 3.

PENGARUH LANGSUNG DAN TIDAK LANGSUNG

\begin{tabular}{|c|c|c|c|c|}
\hline \multirow{2}{*}{$\begin{array}{l}\text { Variabel } \\
\begin{array}{l}\text { On the job embeddedness - Turnover } \\
\text { intention }\end{array}\end{array}$} & \multirow{2}{*}{$\begin{array}{c}\begin{array}{c}\text { Original } \\
\text { Sample }\end{array} \\
-0,279\end{array}$} & \multirow{2}{*}{$\begin{array}{c}\begin{array}{c}T- \\
\text { Statistics }\end{array} \\
2,430\end{array}$} & \multicolumn{2}{|c|}{ Keterangan } \\
\hline & & & $\geq 1,96$ (Signifikan) & Hipotesis Diterima \\
\hline $\begin{array}{l}\text { Off the job embeddedness } \rightarrow \text { Turnover } \\
\text { intention }\end{array}$ & $-0,160$ & 1,464 & $\begin{array}{l}\leq 1,96(\text { Tidak } \\
\text { Signifikan) }\end{array}$ & Hipotesis Ditolak \\
\hline $\begin{array}{l}\text { On the job embeddedness } \rightarrow \text { Affective } \\
\text { commitment }\end{array}$ & 0,231 & 2,850 & $\geq 1,96$ (Signifikan) & Hipotesis Diterima \\
\hline $\begin{array}{l}\text { Off the job embeddedness } \rightarrow \text { Affective } \\
\text { commitment }\end{array}$ & 0,615 & 8,047 & $\geq 1,96$ (Signifikan) & Hipotesis Diterima \\
\hline $\begin{array}{l}\text { Affective commitment } \rightarrow \text { Turnover } \\
\text { intention }\end{array}$ & $-0,371$ & 3,438 & $\geq 1,96$ (Signifikan) & Hipotesis Diterima \\
\hline $\begin{array}{l}\text { On the job embeddedness } \rightarrow \text { Affective } \\
\text { commitment } \rightarrow \text { Turnover intention }\end{array}$ & $-0,086$ & 2,031 & $\geq 1,96$ (Signifikan) & Hipotesis Diterima \\
\hline $\begin{array}{l}\text { Off the job embeddedness } \rightarrow \text { Affective } \\
\text { cmmitment } \rightarrow \text { Turnover intention }\end{array}$ & $-0,228$ & 3,117 & $\geq 1,96$ (Signifikan) & Hipotesis Diterima \\
\hline
\end{tabular}

Sumber: Data diolah (2021)

\section{Pengaruh On the job Embeddedness terhadap Turnover Intention}

Proses pengolahan data yang dilakukan menghasilkan bahwa on the job embeddedness berpengaruh signifikan negatif terhadap turnover intention, sehingga $\mathrm{H} 1$ dapat diterima. Hasil penelitian ini memerkuat penelitian Ampofo et al. (2017); Coetzer et al. (2019); Dawley \& Andrews (2012) bahwa on the job embeddedness berpengaruh negatif dan signifikan terhadap turnover intention.

Melalui wawancara dan observasi yang dilakukan, karyawan Mega Elektronik mengungkapkan bahwa karyawan mendapat fasilitas yang layak berupa lingkungan kerja yang aman dan nyaman, yaitu tempat parkir karyawan yang terpasang CCTV, mushola, dan tempat istirahat karyawan yang bersih. Gaji dan insentif yang diberikan juga disesuaikan dengan tingkatan lamanya masa kerja. Berdasarkan analisis dapat diketahui bahwa on the job embeddedness mampu memengaruhi turnover intention pada karyawan Mega Elektronik. Semakin merasa terikat karyawan pada pekerjaan di Mega Elektronik, maka semakin rendah terjadinya turnover yang dilakukan oleh karyawan. 


\section{Pengaruh Off the job Embeddedness terhadap Turnover Intention}

Hasil uji hiotesis menunjukkan off the job embeddedness tidak berpengaruh secara signifikan terhadap turnover intention sehingga $\mathrm{H} 2$ ditolak. Hasil penelitian ini memerkuat penelitian Ramesh \& Gelfand (2010), bahwa off the job embeddedness tidak berpengaruh secara signifikan terhadap turnover intention. Hasil wawancara yang sudah dilakukan kepada karyawan Mega Elektronik mengungkapkan bahwa mereka bekerja di Mega Elektronik tanpa adanya pengaruh komunitas di luar pekerjaan atau di lingkungan tempat tinggalnya. Selain itu, tidak terdapat serikat pekerja atau organisasi serupa di Mega Elektronik.

Berdasarkan analisis di atas memiliki arti bahwa komunitas maupun kegiatan di luar Mega Elektronik tidak berpengaruh terhadap keinginan karyawan untuk meninggalkan Mega Elektronik, ini menunjukkan bahwa terdapat faktor lain selain off the job embeddedness yang dapat mendeskripsikan turnover intention karyawan. Meskipun karyawan merasa memiliki keharusan untuk berada pada organisasi karena finansial maupun kurangnya lapangan kerja, hal ini tidak memengaruhi turnover intention yang dimiliki oleh karyawan.

\section{Pengaruh On the job Embeddedness terhadap Affective Commitment}

On the job embeddedness berpengaruh positif dan signifikan terhadap affective commitment, sehingga H3 dapat diterima. Hasil penelitian ini memerkuat penelitian Clinton et al. (2012); Ferreira \& Coetzee (2013); Hyun \& Min (2010); Robinson et al. (2014); Shehawy et al. (2018); Williamson \& Holmes (2015) bahwa job embeddedness berpengaruh positif dan signifikan terhadap organizational commitment. Melalui wawancara pada salah satu karyawan Mega Elektronik, mengungkapkan bahwa pemilihan promosi jabatan tidak memandang faktor pendidikan, melainkan karyawan yang sudah bergabung di Mega Elektronik dengan rentang waktu yang lama serta memiliki pribadi yang baik adalah yang mendapat peluang promosi jabatan. Sehingga karyawan yang mendapat peluang promosi tersebut merasa bahagia menghabiskan sisa karirnya di Mega Elektronik. Berdasarkan analisis dapat diketahui bahwa karyawan memiliki tekad yang kuat untuk bertahan di Mega Elektronik yang melibatkan keterikatan emosional karyawan, identifikasi karyawan, dan keterlibatan karyawan pada Mega Elektronik begitupun sebaliknya.

\section{Pengaruh Off the job Embeddedness terhadap Affective Commitment}

On the job embeddedness berpengaruh positif dan signifikan terhadap affective commitment, sehingga H4 dapat diterima. Hasil penelitian ini memerkuat Clinton et al. (2012); Ferreira \& Coetzee (2013); Hyun \& Min (2010); Robinson et al. (2014); Shehawy et al. (2018); Williamson \& Holmes (2015) bahwa job embeddedness berpengaruh positif dan signifikan terhadap organizational commitment. Hasil wawancara dengan karyawan Mega Elektronik mengungkapkan bahwa beliau menyukai komunitas yang berorientasi keluarga. Kekeluargan yang ada di Mega Elektronik antar sesama karyawan mampu meningkatkan keterikatan emosional, contohnya ketika terdapat kendala yang karyawan tersebut tidak dapat mengatasi maka akan diselesaikan bersama saat briefing ataupun sesi evaluasi. Salah satu supervisor juga mengungkapkan bahwa sesi briefing yang rutin diadakan setiap pagi mampu menguatkan kekeluargaan antar karyawan dan membuat karyawan merasa dekat satu sama lain.

\section{Pengaruh Affective Commitment terhadap Turnover Intention}

Uji hipotesis membuktikan affective commitment berpengaruh negatif dan signifikan terhadap turnover intention, sehingga H5 dapat diterima. Hasil penelitian ini diperkuat oleh Faloye (2014) dan Wasti (2003) bahwa affective commitment berpengaruh signifikan dan negatif terhadap turnover intention. Melalui wawancara dan observasi, karyawan Mega Elektronik mengungkapkan bahwa kesulitan mencari pekerjaan menjadikan Mega Elektronik memiliki arti besar baginya, selain itu apabila ada keinginan untuk mencari pekerjaan lain belum tentu perusahaan lain menerima sebagai karyawan. Selain itu, salah satu karyawan Mega Elektronik juga mengatakan beliau merasa aman dan nyaman bekerja di Mega Elektronik, hal yang membuat beliau bertahan yaitu komitmen yang dimilikinya. Dengan pernyataan tersebut diketahui bahwa karyawan Mega Elektronik mempunyai keterikatan secara emosional satu sama lain yang mengakibatkan mereka terikat dengan pekerjaan. 
Annisa Nana Nabella. Efek Mediasi Affective Commitment antara Pengaruh Job Embeddedness terhadap Turnover Intention

\section{Pengaruh Efek Mediasi Affective Commitment antara On the job Embeddedness terhadap Turnover Intention}

Pada studi terdahulu diketahui bahwa variabel mediasi dapat memediasi secara full mediation maupun partial mediation, yang memiliki makna apabila nilai original sample pada pengaruh tidak langsung lebih besar dari pengaruh langsung maka disebut full mediation. Namun, apabila nilai original sample pada pengaruh langsung lebih besar dari pengaruh tidak langsung maka disebut partial mediation. Dari hasil uji hipotesis dapat diketahui affective commitment memediasi pengaruh antara on the job embeddedness terhadap turnover intention sehingga $\mathrm{H} 6$ diterima. Ini menunjukkan bahwa on the job embeddedness berpengaruh secara langsung terhadap turnover intention, dan dapat berpengaruh secara tidak langsung terhadap turnover intention melalui affective commitment, serta terlihat bahwa nilai original sample pengaruh langsung lebih besar dari pengaruh tidak langsung sehingga bermakna affective commitment memiliki peran mediasi yaitu partial mediation. Hasil penelitian ini juga diperkuat oleh Zhao et al. (2012) yang mengungkapkan bahwa job embeddedness berpengaruh signifikan dan negatif terhadap turnover intention melalui affective commitment.

Dikaitkan dengan penelitian yang dilakukan pada Mega Elektronik Nganjuk melalui hasil wawancara karyawan bahwa semakin bertahap karyawan merasakan rasa nyaman dengan Mega Elektronik dalam aspek kerja tim dan juga pencapaian tujuan akan menjadikan adanya keterikatan emosional dan kewajiban moral terhadap perusahaan yang mengakibatkan rendahnya keinginan untuk mencari pekerjaan lain.

\section{Pengaruh Efek Mediasi Affective Commitment antara Off the job Embeddedness terhadap Turnover Intention}

Dari uji hipotesis dapat ditunjukkan bahwa affective commitment memediasi pengaruh antara off the job embeddedness terhadap turnover intention sehingga $\mathrm{H} 7$ diterima. Ini menunjukkan bahwa off the job embeddedness berpengaruh secara langsung terhadap turnover intention, dan dapat berpengaruh secara tidak langsung terhadap turnover intention melalui affective commitment. Hasil penelitian ini diperkuat oleh Zhao et al. (2012) yang mengungkapkan bahwa job embeddedness berpengaruh signifikan dan negatif terhadap turnover intention melalui affective commitment. Selain itu, terlihat bahwa nilai original sample pengaruh tidak langsung lebih besar dari original sample pengaruh langsung sehingga bermakna affective commitment memiliki peran mediasi yaitu full mediation.

Dikaitkan dengan penelitian yang dilakukan pada Mega Elektronik melalui wawancara karyawan perusahaan bahwa sebagian karyawan membutuhkan adanya dukungan organisasi. Sehingga adanya affective commitment diharapkan mampu memengaruhi turnover intention. Tingkat keterikatan \& afeksi terhadap organisasi dapat meningkatkan/menurunkan niat berpindah mereka, mengarahkan mereka untuk meninggalkan/tetap bersama organisasi.

\section{KESIMPULAN}

Kesimpulan penelitian ini adalah: (1) Hubungan on the job embeddedness dengan turnover intention menunjukkan pengaruh yang signifikan negatif; (2) Tidak ada hubungan antara off the job embeddedness dengan turnover intention; (3) Hubungan on the job embeddedness dengan affective commitment menunjukkan pengaruh yang signifikan positif; (4) Hubungan off the job embeddedness dengan affective commitment menunjukkan pengaruh yang signifikan positif; (5) Hubungan affective commitment dengan turnover intention menunjukkan pengaruh yang signifikan negatif; (6) Affective commitment memediasi pengaruh antara on the job embeddedness terhadap turnover intention; (7) Affective commitment memediasi pengaruh antara off the job embeddedness terhadap turnover intention.

Perusahaan disarankan untuk melaksanakan pengawasan secara berkala pada fasilitas yang ada dan melakukan peningkatan, karena hal tersebut mampu membuat karyawan bertahan. Perusahaan sebaiknya mempertahankan rutinitas sesi briefing pagi dan evaluasi, karena dari situ mampu terjalin komunikasi dua arah antara karyawan dengan supervisor yang mampu meningkatkan rasa kekeluargaan dan keterikatan antar karyawan. Perusahaan sebaiknya memberi perhatian khusus 
terhadap perasaan ingin meninggalkan perusahaan yang dimiliki karyawan dengan komunikasi yang baik, agar kendala yang ada dalam pekerjaan maupun perasaan yang dialami karyawan dapat tersampaikan dan mendapat solusi yang terbaik. Perusahaan sebaiknya meningkatkan gaji ataupun insentif sesuai dengan kemampuan perusahaan.

Penelitian ini telah dilaksanakan sesuai dengan prosedur ilmiah, namun masih memiliki keterbatasan yaitu dalam proses pengambilan data, informasi yang diberikan responden melalui kuesioner terkadang tidak menunjukkan pendapat responden yang sebenarnya. Hal ini terjadi karena kadang perbedaan pemikiran, anggapan dan pemahaman yang berbeda tiap responden, juga faktor lain seperti faktor kejujuran dalam pengisian pendapat responden dalam kuesionernya. Penelitian selanjutnya dapat menggali kembali faktor-faktor yang mengurangi turnover intention pada karyawan seperti faktor atau variabel dukungan supervisor, kepemimpinan, dan teamwork.

\section{DAFTAR PUSTAKA}

Ahmad, B., \& Shahid, N. (2020). The Employee's Organizational Commitment and Its Impact on The Turnover Intentions among Employees of The Organization. Journal of Pakistan Psychiatric Society, 17(1), 9-12.

Ali, N., Ali, Z., \& Khan, A. (2011). The Relationship between Ostracism and Turnover Intention: Role of Commitment as a Mediator. Global Sosial Sciences Review, 3(4), 389-399. https://doi.org/10.31703/gssr.2018(III-IV).26

Allen, D. G. (2006). Do Organizational Socialization Tactics Influence Newcomer Embeddedness and Turnover? Journal of Management, 32(2), 237-256. https://doi.org/10.1177/0149206305280103

Allen, N. J., \& Meyer, J. P. (1990). Organizational Socialization Tactics: A Longitudinal Analysis of Links to Newcomers' Commitment and Role Orientation. Academy of Management Journal, 33(4), 847-858. https://doi.org/10.5465/256294

Ampofo, E. Y., Coetzer, A., \& Susomrith, P. (2017). The Job Embeddedness-Turnover Intentions Relationship: Evidence from Thailand. Stream 3: Entrepreneurship, Start-Ups and Small Business Competitive Session, January.

Bambacas, M., \& Kulik, T. C. (2013). Job Embeddedness in China: How HR Practices Impact Turnover Intentions. International Journal of Human Resource Management, 24(10), 19331952. https://doi.org/10.1080/09585192.2012.725074

Chan, W. L., Ho, J. A., Sambasivan, M., \& Ng, S. I. (2019). Antecedents and Outcome of Job Embeddedness: Evidence from Four and Five-star Hotels. International Journal of Hospitality Management, 83, 37-45. https://doi.org/10.1016/j.ijhm.2019.04.011

Cho, D., \& Son, J. (2012). Job Embeddedness and Turnover Intentions : An Empirical Investigation of Construction IT Industries. International Journal of Advanced Science and Technology, 40, $101-110$.

Clinton, M., Knight, T., \& Guest, D. E. (2012). Job Embeddedness: A New Attitudinal Measure. International Journal of Selection and Assessment, 20(1), 111-117. https://doi.org/10.1111/j.1468-2389.2012.00584.x

Coetzer, A., Inma, C., Poisat, P., Redmond, J., \& Standing, C. (2019). Does Job Embeddedness Predict Turnover Intentions in SMEs? International Journal of Productivity and Performance Management, 68(2), 340-361. https://doi.org/10.1108/IJPPM-03-2018-0108 
Annisa Nana Nabella. Efek Mediasi Affective Commitment antara Pengaruh Job Embeddedness terhadap Turnover Intention

Crossley, C. D., Bennett, R. J., Jex, S. M., \& Burnfield, J. L. (2007). Development of A Global Measure of Job Embeddedness and Integration into A Traditional Model of Voluntary Turnover. Journal of Applied Psychology, 92(4), 1031-1042. https://doi.org/10.1037/00219010.92.4.1031

Dawley, D. D., \& Andrews, M. C. (2012). Staying Put: Off-the-job Embeddedness as A Moderator of The Relationship between On-the-job Embeddedness and Turnover Intentions. Journal of Leadership and Organizational Studies, 19(4), 477-485. https://doi.org/10.1177/1548051812448822

Faisal, S., Naushad, M., \& Faridi, M. R. (2020). A Study on The Level and Relationship of Job Embeddedness and Turnover Intentions among Saudi Arabian Working-class. Management Science Letters, 10, 3167-3172. https://doi.org/10.5267/j.msl.2020.5.005

Faloye, D. O. (2014). Organisational Commitment and Turnover Intentions: Evidence from Nigerian Paramilitary Organisation. International Journal of Business and Economic Development (IJBED), 2(3), 23-34. www.ijbed.org

Feldman, D. C., Ng, T. W. H., \& Vogel, R. M. (2012). Off-the-job Embeddedness: A Reconceptualization and Agenda for Future Research. In Research in Personnel and Human Resources Management (Vol. 31). Emerald Group Publishing Limited. https://doi.org/10.1108/S0742-7301(2012)0000031008

Felps, W., Mitchell, T., Hekman, D., Lee, T. W., Holtom, B. C., \& Harman, W. S. (2009). Turnover Contagion: How Coworkers' Job Embeddedness and Job Search Behaviors Influence Quitting. Academy of Management Journal, 52(3), 545-561. https://doi.org/10.5465/AMJ.2009.41331075

Ferreira, N., \& Coetzee, M. (2013). The Influence of Job Embeddedness on Black Employees' Organisational Commitment. Southern African Business Review, 17(3), 239-255.

Firmanto, T., \& Kistyanto, A. (2013). Pengaruh Budaya Kerja Kekeluargaan terhadap Turnover Intention Karyawan melalui Komitmen Afektif. Jurnal Ilmu Manajemen (JIM), 1(1), 250-259.

Gonzalez, J. A., Ragins, B. R., Ehrhardt, K., \& Singh, R. (2016). Friends and Family: The Role of Relationships in Community and Workplace Attachment. Journal of Business and Psychology, 33(1), 89-104. https://doi.org/10.1007/s10869-016-9476-3

Gozhali, I. ., \& Latan, H. (2015). Partial Least Squares Konsep, Teknik dan Aplikasi Menggunakan Program SmartPLS 3.0 Untuk Penelitian Empiris. Semarang: Badan Penerbit Universitas Diponegoro.

Hadi, D. M., \& Nugraheni, R. (2018). Pengaruh Kontrak Psikologis Relasional dan Kontrak Psikologis Transaksional terhadap Komitmen Organisasional (Studi pada Karyawan Non Medis di Rumah Sakit Roemani Muhammadiyah Kota Semarang). Diponegoro Journal of Management, 7(4), 1-12.

Halbesleben, J. R. B., \& Wheeler, A. R. (2008). The Relative Roles of Engagement and Embeddedness in Predicting Job Performance and Intention to Leave. Work and Stress: An International Journal of Work, Health, \& Organisations, 22(3), 242-256. https://doi.org/10.1080/02678370802383962

Harman, W. S., Blum, M., Stefani, J., \& Taho, A. (2009). Albanian Turnover: Is the Job Embeddedness Construct Predictive in an Albanian Context? Journal of Behavioral and Applied Management, 10(2), 192-205. 
Hefny, L. (2020). The Relationships between Job Satisfaction Dimensions, Organizational Commitment and Turnover Intention: The Moderating Role of Ethical Climate in Travel Agencies. Journal of Human Resources in Hospitality and Tourism, 0(0), 1-23. https://doi.org/10.1080/15332845.2020.1821425

Hom, P. W., Tsui, A. S., Wu, J. B., Lee, T. W., Zhang, A. Y., Fu, P. P., \& Li, L. (2009). Explaining Employment Relationships With Social Exchange and Job Embeddedness. Journal of Applied Psychology, 94(2), 277-297. https://doi.org/10.1037/a0013453

Hyun, D. H., \& Min, S. K. (2010). Effects of Job Embeddedness on Job Satisfaction, Organizational Commitment and Turnover Intention - Focused on Employees of Hotel F \& B Division -. The Journal of the Korea Contents Association, 26(1), 1-12. https://doi.org/10.5392/jkca.10.10.418

Jiang, K., Liu, D., McKay, P. F., Lee, T. W., \& Mitchell, T. R. (2012). When and How is Job Embeddedness Predictive of Turnover? A Meta-analytic Investigation. Journal of Applied Psychology, 97(5), 1077-1096. https://doi.org/10.1037/a0028610

Joarder, M. H. R., Sharif, M. Y., \& Ahmmed, K. (2011). Mediating Role of Affective Commitment in HRM Practices and Turnover Intention Relationship: A Study in a Developing Context. Business and Economics Research Journal, 2(4), 135-158.

Kim, Y., \& Kang, Y. (2015). Effects of Self-efficacy, Career Plateau, Job Embeddedness, and Organizational Commitment on The Turnover Intention of Nurses. Journal of Korean Academy of Nursing Administration, 21(5), 530-541. https://doi.org/10.11111/jkana.2015.21.5.530

Lee, D.-C., Hung, L.-M., \& Chen, M.-L. (2012). Empirical Study on the Influence among Corporate Sponsorship, Organizational Commitment, Organizational Cohesiveness and Turnover Intention. Journal of Management and Sustainability, 2(2). https://doi.org/10.5539/jms.v2n2p43

Lee, Thomas W., Mitchell, T. R., Sablynski, C. J., Burton, J. P., \& Holtom, B. C. (2004). The Effects of Job Embeddedness on Organizational Citizenship, Job Performance, Volitional Absences, and Voluntary Turnover. Academy of Management Journal, 47(5), 711-722. https://doi.org/10.2307/20159613

Lee, Thomas William, Burch, T. C., \& Mitchell, T. R. (2014). The Story of Why We Stay: A Review of Job Embeddedness. Annual Review of Organizational Psychology and Organizational Behavior, 1, 199-216. https://doi.org/10.1146/annurev-orgpsych-031413-091244

Lew, T. (2011). Affective Organizational Commitment and Turnover Intention of Academics in Malaysia. International Conference on Business and Economics Research, 1, 110-114.

Maska, H., \& Riyanto, S. (2020). The Influence of Job Embeddedness, Salary, and Organizational Commitment Against The Turnover Intention of The Employees in The Marketing Division at Pharmaceutical Laboratories Industry in Jabodetabek. IOSR Journal of Business and Management, 22(2), 29-35. https://doi.org/10.9790/487X-2202062935

Mercurio, Z. A. (2015). Affective Commitment as A Core Essence of Organizational Commitment: An Integrative Literature Review. Human Resource Development Review, 14(4), 389-414. https://doi.org/10.1177/1534484315603612

Merhar, C. (2020). Employee Retention - The Real Cost of Losing Employee. PeopleKeep. https://www.peoplekeep.com/blog/employee-retention-the-real-cost-of-losing-an-employee

Meyer, J. P., Allen, N. J., \& Smith, C. A. (1993). Commitment to Organizations and Occupations: 
Annisa Nana Nabella. Efek Mediasi Affective Commitment antara Pengaruh Job Embeddedness terhadap Turnover Intention

Extension and Test of A Three-component Conceptualization. Journal of Applied Psychology, 78(4), 538-551. https://doi.org/10.1037//0021-9010.78.4.538

Mitchell, T. R., Holtom, B. C., Lee, T. W., Sablynski, C. J., \& Erez, M. (2001). Why People Stay: Using Job Embeddedness to Predict Voluntary Turnover. Academy of Management Journal, 44(6), 1102-1121. https://doi.org/10.2307/3069391

Ng, T. W., \& Feldman, D. C. (2014). Community Embeddedness and Work Outcomes: The Mediating Role of Organizational Embeddedness. Human Relations, 67(1), 71-103. https://doi.org/10.1177/0018726713486946

Peachey, J. W., Burton, L. J., \& Wells, J. E. (2014). Examining The Influence of Transformational Leadership, Organizational Commitment, Job Embeddedness, and Job Search Behaviors on Turnover Intentions in Intercollegiate Athletics. Leadership \& Organization Development Journal, 35(8), 740-755. https://doi.org/https://doi.org/10.1108/LODJ-10-2012-0128

Price, J. L. (2000). Reflections on The Determinants of Voluntary Turnover. International Journal of Manpower, 22(7), 600-624.

Ramesh, A., \& Gelfand, M. J. (2010). Will They Stay or Will They Go? The Role of Job Embeddedness in Predicting Turnover in Individualistic and Collectivistic Cultures. Journal of Applied Psychology, 95(5), 807-823. https://doi.org/10.1037/a0019464

Reitz, O. E., \& Anderson, M. A. (2011). An Overview of Job Embeddedness. Journal of Professional Nursing, 27(5), 320-327. https://doi.org/10.1016/j.profnurs.2011.04.004

Ridlo, I. A. (2012). Turn Over (Literature Review) in Bahasa for Healthcare. Surabaya: PHMovement Publication.

Robinson, R. N. S., Kralj, A., Solnet, D. J., Goh, E., \& Callan, V. (2014). Thinking Job Embeddedness Not Turnover: Towards a Better Understanding of Frontline Hotel Worker Retention. International Journal of Hospitality Management, 36, 101-109. https://doi.org/10.1016/j.ijhm.2013.08.008

Shafique, M., Qadeer, F., Ahmad, M., \& Rehman, R. (2011). Impact of Job Embeddedness on Leave Intention: An Understanding from Higher Education (HE) System. African Journal of Business Management, 5(30), 11794-11801. https://doi.org/10.5897/ajbm10.466

Shehawy, Y. M., Elbaz, A., \& Agag, G. M. (2018). Factors Affecting Employees' Job Embeddedness in The Egyptian Airline Industry. Tourism Review, 73(4), 548-571. https://doi.org/10.1108/TR03-2018-0036

Singh, B., Shaffer, M. A., \& Selvarajan, T. T. (2017). Antecedents of Organizational and Community Embeddedness: The Roles of Support, Psychological Safety, and Need to Belong. Journal of Organizational Behavior, 1-16. https://doi.org/10.1002/job.2223

Sousa-Poza, A., \& Henneberger, F. (2004). Analyzing Job Mobility with Job Turnover Intentions: An International Comparative Study. Journal of Economic Issues, 38(1), 113-137. https://doi.org/10.1080/00213624.2004.11506667

Suyono, J., Eliyana, A., \& Ratmawati, D. (2020). The Nightmare of Turnover Intention for Companies in Indonesia. Revista de Ciencias Humanas y SOciales, 6, 871-888.

Takawira, N., Coetzee, M., \& Schreuder, D. (2014). Job Embeddedness, Work Engagement and Turnover Intention of Staff in A Higher Education Institution: An Exploratory Study. SA 
Journal of Human Resource Management, 12(1), 1-10. https://doi.org/10.4102/sajhrm.v12i1.524

Thome, M. J., \& Greenwald, J. M. (2020). Job and Community Embeddedness on Voluntary Turnover. Journal of Business and Industrial Marketing. https://doi.org/10.1108/JBIM-012019-0021

Tian, A. W., Cordery, J., \& Gamble, J. (2016). Staying and Performing: How Human Resource Management Practices Increase Job Embeddedness and Performance. Personnel Review, 45(5), 947-968. https://doi.org/10.1108/PR-09-2014-0194

Treuren, G. J. M., \& Fein, E. C. (2021). Off-the-job Embeddedness as A Moderator of The Relationship between Work and Life Conflict and Turnover Intention. International Journal of Human Resource Management, 32(6), 1251-1272. https://doi.org/10.1080/09585192.2018.1510847

Uludag, O., Khan, S., \& Guden, N. (2011). The Effects of Job Satisfaction and Organizational Commitment on Organizational Citizenship Behavior. Florida International University Hospitality Review, 29(2), 1-21. https://doi.org/10.20885/jsb.vol19.iss2.art1

Usman, M., Javed, U., Shoukat, A., \& Bashir, N. A. (2019). Does Meaningful Work Reduce Cyberloafing? Important Roles of Affective Commitment and Leader-member Exchange. Behaviour and Information Technology, 40(2), 206-220. https://doi.org/10.1080/0144929X.2019.1683607

Vandenberghe, C., Panaccio, A., \& Ben Ayed, A. K. (2011). Continuance Commitment and Turnover: Examining The Moderating Role of Negative Affectivity and Risk Aversion. Journal of Occupational and Organizational Psychology, 84, 403-424. https://doi.org/10.1348/096317910X491848

Wasti, S. A. (2003). Organizational Commitment, Turnover Intentions and The Influence of Cultural Values. Journal of Occupational and Organizational Psychology, 76, 303-321. https://doi.org/10.1348/096317903769647193

Wasti, S. A., \& Can, Ö. (2008). Affective and Normative Commitment to Organization, Supervisor, and Coworkers: Do Collectivist Values Matter? Journal of Vocational Behavior, 73, 404-413. https://doi.org/10.1016/j.jvb.2008.08.003

Williamson, I. O., \& Holmes, O. (2015). What's Culture Got to Do with It? Examining Job Embeddedness and Organizational Commitment and Turnover Intentions in South Africa. Africa Journal of Management, 1(3), 225-243. https://doi.org/10.1080/23322373.2015.1056649

Yang, Juan, Pu, B., \& Guan, Z. (2019). Entrepreneurial Leadership and Turnover Intention in Startups: Mediating Roles of Employees' Job Embeddedness, Job Satisfaction and Affective Commitment. Sustainability (Switzerland), 11(4). https://doi.org/10.3390/su11041101

Yang, Jen Te. (2008). Effect of Newcomer Socialisation on Organisational Commitment, Job Satisfaction, and Turnover Intention in The Hotel Industry. Service Industries Journal, 28(4), 429-443. https://doi.org/10.1080/02642060801917430

Yu, J., Ariza-Montes, A., Giorgi, G., Lee, A., \& Han, H. (2020). Sustainable Relationship Development between Hotel Company and Its Employees: Linking Job Embeddedness, Job Satisfaction, Self-efficacy, Job Performance, Work Engagement, and Turnover. Sustainability (Switzerland), 12(17). https://doi.org/10.3390/su12177168 
Annisa Nana Nabella. Efek Mediasi Affective Commitment antara Pengaruh Job Embeddedness terhadap Turnover Intention

Zainuddin, Y., \& Noor, A. (2019). The Role of Job Embeddedness and Organizational Continuance Commitment on Intention to Stay: Development of Research Framework and Hypotheses. KnE Social Sciences, 2019, 1017-1035. https://doi.org/10.18502/kss.v3i22.5108

Zhao, X., Sun, T., Cao, Q., Li, C., Duan, X., Fan, L., \& Liu, Y. (2012). The Impact of Quality of Work Life on Job Embeddedness and Affective Commitment and Their Co-effect on Turnover Intention of Nurses. Journal of Clinical Nursing, 22(5-6), 780-788. https://doi.org/10.1111/j.1365-2702.2012.04198.x

Zhou, H., Long, L. R., \& Wang, Y. Q. (2009). What is The Most Important Predictor of Employees' Turnover Intention in Chinese Call Centre: Job Satisfaction, Organisational Commitment or Career Commitment? International Journal of Services, Technology and Management, 12(2), 129-145. https://doi.org/10.1504/IJSTM.2009.025231 